\title{
IZBIRANJE OPTIMALNIH POTI ZA PREVOZ NEVARNIH SNOVI S POMOČJO TEHNOLOGIJE GEOGRAFSKIH INFORMACIJSKIH SISTEMOV
}

\author{
Marjan Žura
}

UDK 656.1:91:681.3

Izvleček

Prevozi nevarnih snovi predstauljajo vedno večji problem. Odstotek in teža prometnih nezgod vozil, ki prevažajo nevarne snovi, zelo hitro naraščata. Očitno obstoječa regulativa ne zadošča in je potrebna podpora sodobnega računalniško podprtega informacijskega sistema. $V$ prispevku je predstavljen interaktiuni model za določanje optimalne poti (poti z najmanjšim tveganjem) za prevoze nevarnih snovi, ki je rezultat projekta, ki sta ga financirali Ministrstvo za promet in zveze ter Ministrstuo za notranje zadeve. Namen projekta je bil vzpostavitev računalniško podprtega informacijskega sistema za podporo odločitvam pri prevažanju nevarnih snovi po cestni mreži $R$ Slovenije. Sistem je zasnovan na tehnologiji geografskih informacijskih sistemov (GIS) in je izdelan s paketom PC ARCINFO na osebnih računalnikih. $V$ prihodnosti bo sistem del kompleksnega prostorskega informacijskega sistema $R$ Slovenije.

UDC $656.1: 91: 681.3$

\section{Abstract \\ SELECTING THE MINIMUM RISK ROUTE IN THE TRANSPORTATION OF HAZARDOUS MATERIALS}

The transportation of hazardous materials is a broad and complex topic. Percent and weight of accidents of vehicles carrying dangerous goods are growing fast. Modern computer based information system for dangerous materials management is becoming more and more important. In this paper I present an interactive software system for minimum risk route selection based on the PC ARC/INFO. The model computes optimal path based on accident probabiliti is computed from traffic accident rates, highway operational speed, traffic volume and technical characteristic of the roadwidth, radius and slope. Dangerous goods are classified into nine classes according to their impact to different sensible environment elements. Those sensible elements are drinking water resourses, natural heritage, forestry, agricultural areas, cultural heritage, urban areas and tourist resorts. Some results of system implementation on Slovenia road network are be presented.

Dr. Marijan Žura, dipl. ing., FAGG Prometnotehniški inštitut, Jamova 2, 61000 Ljubljana 


\section{UVOD}

Prevozi nevarnih snovi predstavljao vedno večji problem. Odstotek in teža prometnih nezgod vozil, ki prevažajo nevarne snovi, zelo hitro naraščata. Očitno obstoječa regulativa za prevoze nevarnih snovi ne zadošča in je potrebna podpora sodobnega računalniško podprtega informacijskega sistema. V tem prispevku predstavljamo interaktiven model za določanje optimalne poti (pot $z$ najmanjšim tveganjem) za prevoze nevarnih snovi, ki je rezultat projekta, ki sta ga financirali Ministrstvo za promet in zveze ter Ministrstvo za notranje zadeve. namen projekta je bil vzpostavitev računalniško podprtega informacijskega sistema za podporo odločitvam pri prevažanju nevarnih snovi po cestni mreži $\mathrm{R}$ Slovenije. Sistem je zasnovan na tehnologiji geografskih informacijskih sistemov (GIS) in je izdelan s paketom PC ARC/INFO na osebnih računalinkih. V bodočnosti bo sistem del kompleksnega prostorskega informacijskega sistema $\mathrm{R}$ Slovenije.

\section{PODATKOVNI MODEL}

V procesu vzpostavitve sistema smo morali izdelati naslednje računalniške evidence:

- kataster nevarnih snovi,

- kataster cest,

- kataster varovalnih območij.

\section{KATASTER NEVARNIH SNOVI}

Vnesti smo morali podatke o stopnjah nevarnosti različnih kategorij nevarnih snovi za posamezne vrste ogroženih območij (gozdovi, vodni viri ...). Nevarne snovi razvrstimo $\mathrm{v}$ naslednje skupine:

Tabela 1. Kataster nevarnih snovi

1. eksplozivi

2. plini

a. eksplozivne snovi

b. predmeti, polnjeni $z$ eksplozivnimi snovmi

- Z,M,n,k

c. vžigalna sredstva

$-\mathrm{Z}, \mathrm{M}$

$-\mathrm{z}, \mathrm{m}, \mathrm{k}$

3. vnetljive točke

- v,Z,M,n,k

- V,Z,M,N,K

4. trdne snovi

4.1 vnetljive trdne snovi

- $\mathrm{z}, \mathrm{m}$

4.2 samovnetljive snovi

4.3 snovi, ki $\mathrm{v}$ stiku $\mathrm{z}$ vodo razvijajo vnetljive pline

- v,Z,M,k

5. oksidirajoče snovi

- v,Z,m,n

5.1 oksidirajoče snovi 
6. strupi

5.2 organski peroksidi

- V,Z,M,N

6.1 strupi

6.2 gabljive in kužne snovi

- V,Z,M,N,K

- V,z,M,K

7. radioaktivne snovi

8. jedke snovi

- V,z,M,N,K

9. druge nevarne snovi

$-\mathrm{v}, \mathrm{z}, \mathrm{m}, \mathbf{n}, \mathbf{k}$

\begin{tabular}{lll}
\hline Legenda: & V & voda \\
& Z & zrak \\
M & mesta \\
N & naravna dediščina \\
K & kulturna dediščina \\
X & velika nevarnost \\
& X & majhna nevarnost \\
\hline
\end{tabular}

Občutljivost posameznih delov prostora se razlikuje glede na vrsto nevarnih snovi. Tako predstavljajo npr. nevarne snovi razreda 3 (vnetljive tekočine) veliko nevarnost za vodne vire, medtem ko nevarne snovi razreda 1 a (eksplozivne snovi) ne predstavljajo nevarnosti za vodne vire.

\section{KATASTER CEST}

Cestna mreža omogoča povezavo med posameznimi točkami prostora, po drugi strani pa njeno stanje in njeni geometrijski elementi v veliki meri vplivajo na varnost prevozov nevarnih snovi. Zato moramo vzpostaviti podatkovno bazo o stanju cestne mreže. V prvi fazi je bila vzpostavljena podatkovna baza magistralne in regionalne cestne mreže. Kot grafična osnova so bile privzete osi cest, ki so bile digitalizirane s karte 1:250000, atributivni podatki pa so bili prenešeni iz banke cestnih podatkov Republiške uprave za ceste. Za optimizacijo prevozov nevarnih snovi so potrebni podatki o naslednjih elementih cest:

- horizontalni potek,

- vzdolžni nagibi,

- širine,

- nosilnost.

Za določanje optimalne poti prevozov s težkimi tovornimi vozili in vlačilci moramo poznati lokacije odsekov, katerih horizontalni elementi, vzdolžni nagibi, širine ali nosilnost ne omogočajo varne vožnje težkih ali dolgih vozil. Odseki $\mathrm{z}$ neprimernimi horizontalnimi elementi so določeni s številko odseka po nomenklaturi Republiške uprave za ceste ter s stacionažo začetka in konca pododseka $z$ neprimernimi elementi. 


\section{KATASTER VAROVANIH OBMOČIJ}

Kljub temu da predstavljajo nevarne snovi grožnjo celotnemu prostoru, v katerem živimo, obstajajo določeni deli oziroma elementi prostora, ki jih hočemo posebej varovati zaradi njihove posebne občutljivosti, redkosti ali iz drugih vzrokov. Med najpomembnejšimi elementi prostora so nedvomno vodni viri (reke, jezera, območja podtalnice), naravna in kulturna dediščina, naselja, turistična območja, gozdovi posebnega pomena in kmetijske površine prve kategorije. Kataster varovalnih območij smo vzpostavili $z$ digitalizacijo oz. skeniranjem kart, ki so bile osnova za izdelavo dolgoročnega plana Slovenije od leta 1986 do leta $2000 \mathrm{v}$ merilu 1:250000.

\section{MODEL VREDNOTENJA VAROVANIH OBMOČIJ}

Na posameznih delih prostora lahko pride do sovpadanja več različnih varovanih elementov okolja, npr. kmetijska površina prve kategorije in pomembnejše območje podtalnice itd. Območja $z$ več varovanimi elementi moramo še posebej šcititi pred prevozom nevarnih snovi. Zato moramo izdelati računalniški model prostora, v katerem so zajeti vsi dejavniki okolja, ki jih moramo varovati. Tehnologija geografskih informacijskih sistemov je idealno orodje za modeliranje takih problemov. S topološkim prekrivanjem vseh $v$ prejšnjem poglavju naštetih informacijskih slojev dobimo nov informacijski sloj, kjer posamezni poligoni predstavljajo območja $z$ enim, dvema, tremi itd. varovanimi elementi. Matematični model za vrednotenje posameznih vrst varovanih območij je precej poenostavljen. Najtežji korak pri vzpostavitvi je določitev vrednostnih kriterijev posameznih vrst varovanih območij, zato smo $v$ tej fazi privzeli poenostavljen model $z$ enotnimi utežnimi faktorji. Karta vrednosti varovalnih območij je prikazana na sliki 1 .

\section{ISKANJE OPTIMALNIH POTI}

Kadar se prevozu nevarnih snovi ne moremo izogniti, moramo poiskati tako pot med dvema mestoma, ki bo predstavljala najmanjšo nevarnost za okolje. Izdelali smo računalniški model cestne mreže, ki upošteva podatke o operativnih hitrostih vozil, neustreznih elementih horizontalnega in vertikalnega poteka, širinah in nosilnosti. Vrednost prostora vključimo $\mathbf{v}$ model tako, da topološko prekrijemo model cestne mreže $z$ modelom prostora, opisanim v prejšnjem poglavju. Tako dobimo za vsak pododsek cestne mreže podatke o dolžini, operativni hitrosti in vrednosti prostora. Optimalna pot med dvema točkama je tista, ki ima najmanjšo vrednost izraza upor=dolžina pododseka/razred hitrosti-občutljivost, 
Slika 1: Vrednosti varovanih območij.

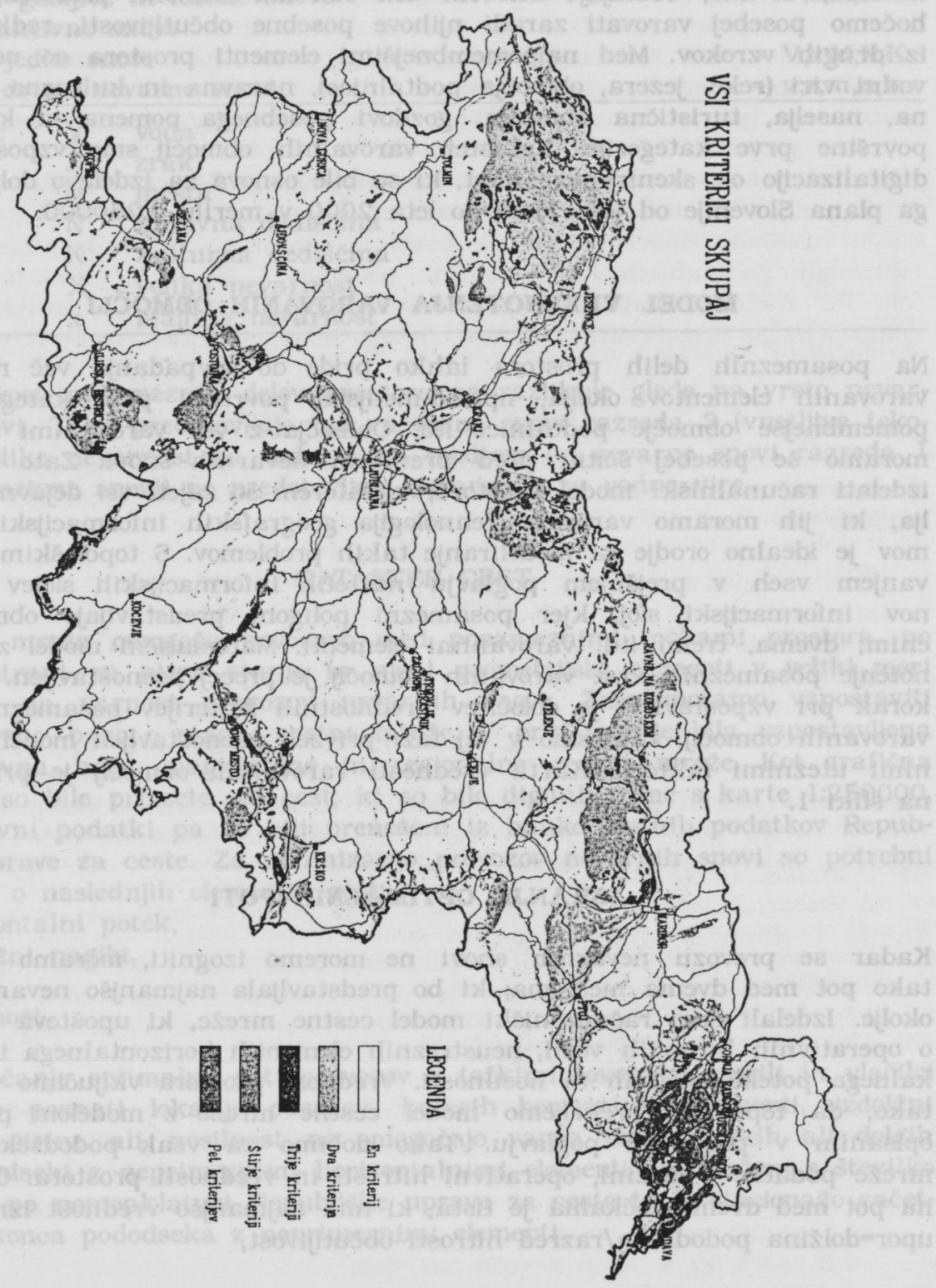


kjer so razredi:

1. do $40 \mathrm{~km} / \mathrm{h}$

2. $40-60 \mathrm{~km} / \mathrm{h}$

3. $60-80 \mathrm{~km} / \mathrm{h}$

4. nad $80 \mathrm{~km} / \mathrm{h}$

občutljivost prostora pa je odvisna od razreda nevarne snovi

Izdelali smo programsko opremo, ki za vsak prevoz nevarnih snovi interaktivno omogoča:

1. Izločitev cest, ki tehnično ne ustrezajo karakteristikam vozila, ki prevaža nevarno snov. $\mathrm{V}$ tem koraku je treba izločiti odsek $\mathrm{z}$ :

- neustreznimi širinami vozišča,

- neustreznimi vzponi in padci,

- neustreznimi radiji,

- neustrezno nosilnostjo.

2. Določitev vrst območij, ki so ogrožena s prevozom nevarnih snovi.

3. Priključevanje ponderiranih vrednosti varovanih obmožij, ki ležijo ob cestah.

4. Iskanje optimalne poti po cestni mreži, pri čemer se kot kriterij upošteva najnižja kumulativna vrednost prevožene poti.

5. Izris poteka optimalne poti in izpis seznama odsekov.

\section{ZAKLJUČEK}

Prevozi nevarnih snovi predstavljajo resno grožnjo okolju, v katerem živimo. S pomočjo sodobnega računalniškega informacijskega sistema za podporo odločitev pri prevozih nevarnih snovi lahko to nevarnost zmanjšamo na najmanjšo možno mero. $\mathrm{V}$ okviru tega projekta je bila izdelana prva verzija tega informacijskega sistema. V podatkovni bazi so zajeti bistveni podatki o cestah ter podatki o varovanih elementih prostora. Izdelana je aplikacija, ki omogoča interaktivno določevanje optimalne poti med dvema mestoma. Optimalna pot je tista, ki predstavlja najmanjšo grožnjo okolju. $\mathrm{V}$ tem projektu je bil uporabljen poenostavljen model vrednotenja prostora, saj so vsi varovalni elementi enakovredni. Pravilna vrednostna razmerja med posameznimi elementi bi bilo potrebno raziskati $\mathrm{v}$ posebnem projektu. Ravno tako $v$ tem modelu ni upoštevano stanje prometne varnosti na cestah in verjetnost ponavljanja nezgod.

\section{LITERATURA IN VIRI}

Brogan, J. D., J. W. Cashwell: Routing Models for the Transportation of Hazardous Materials-State Level Enhancements and Modifications. Transportation Research Record 1020.

Pijawka, K. D. et al.: Risk Assessment of Transportation Hazardous Material: Route Analysis and Hazard Management. Transportation Research Record 1020. 
Saccomano, F. F., A. Y. W. Chan: Economic Evaluation of Routing Strategies for Hazardous Road Shipments. Transportation Research Record 1020.

Saccomano et al:: Interactive Selection of Minimum-Risk Routes for Dangerous Goods Shipments. Transportation Research Record 1148.

Scanlon, D. R., E. J. Cantilli: Assessing the Risk and Safety in the Transportation of Hazardous Materials. Transportation Research Record 1020.

Zemljič, V., 1990: Možnosti prevoza nevarnih snovi na območju Republike Slovenije, Ljubljana 